\title{
It is all in your head: a model for cerebral malaria
}

\author{
Antoine Claessens ${ }^{1 *}$, Zbynek Bozdech², Alex Rowe $^{1}$ \\ From Parasite to Prevention: Advances in the understanding of malaria \\ Edinburgh, UK. 20-22 October 2010
}

Cerebral malaria is characterised by an accumulation of infected erythrocytes in the microvasculature of the brain. P. falciparum infected erythrocytes have been shown to bind to a Human Brain Endothelial Cell line (HBEC-5i), however, the parasite adhesion ligands necessary to anchor the infected erythrocytes onto HBEC-5i have not been identified. We aimed to identify parasite variant surface antigens that are differentially transcribed after selection for cytoadherence to HBEC-5i.

The P. falciparum laboratory strains 3D7, HB3 and IT/FCR3 were selected using a panning assay for binding to HBEC-5i. In order to analyse their transcriptome using a microarray chip based on the 3D7 genome, variant surface antigens sequences (var/PfEMP1, rif, stevor) were extracted from the sequenced HB3 and IT genomes and added to the 3D7-based microarray chip.

Microarray analysis was carried out on selected and unselected parasites of all three strains. Transcriptome data clearly indicated that the most highly upregulated genes after selection were group A or group A-like var genes, showing 11 to over 100 fold upregulation in selected parasites. The rif gene located head-to-head to the upregulated var gene was also highly expressed. To a lesser extent some exported proteins like RESA-1, PfEMP3 or PHIST family members also showed increased transcription in HBEC-selected parasites (2-3 fold upregulation). Reverse transcriptase-PCR confirmed the upregulation of group A var genes in selected parasites, suggesting that the group A PfEMP1 variants are major candidate ligands for parasite binding to HBEC$5 i$. These findings are consistent with previous work showing an association between group A var genes and cerebral malaria.

The HBEC-5i receptors mediating this interaction with infected erythrocytes are currently under investigation.

'IIIR, Ashworth Laboratories, University of Edinburgh, Edinburgh, EH9 3JT, UK Full list of author information is available at the end of the article
Author details

${ }^{1}$ IIIR, Ashworth Laboratories, University of Edinburgh, Edinburgh, EH9 3JT, UK. ${ }^{2}$ Nanyang Technological University, SBS, 60 Nanyang Drive, 637551,

Singapore.

Published: 16 December 2010

doi:10.1186/1475-2875-9-S2-P63

Cite this article as: Claessens et al:: It is all in your head: a model for cerebral malaria. Malaria Journal 2010 9(Suppl 2):P63.

Submit your next manuscript to BioMed Central and take full advantage of:

- Convenient online submission

- Thorough peer review

- No space constraints or color figure charges

- Immediate publication on acceptance

- Inclusion in PubMed, CAS, Scopus and Google Scholar

- Research which is freely available for redistribution 